\title{
The impact of oral dexamethasone on Toll-like receptor levels in neonatal rat intestine
}

\author{
TARIK PURTULOGLU ${ }^{1}$, GOKHAN AYDEMIR ${ }^{2}$ MEHMET SALDIR ${ }^{3}$, ABDULBAKI KARAOGLU, \\ GALIP ERDEM ${ }^{3}$, KURSAT M. FIDANCI ${ }^{4}$, OGUZHAN BABACAN ${ }^{3}$ FERHAT CEKMEZ, \\ TURAN TUNC ${ }^{5}$, HALIL YAMAN ${ }^{6}$, SERDAR UMIT SARICI ${ }^{5}$
}

${ }^{1}$ Department of Anesthesiology, Gulhane Military Medical Faculty, Ankara, Turkey

${ }^{2}$ Haydarpasa Training Hospital, Gulhane Military Medical Faculty, Department of Pediatrics, Istanbul, Turkey

${ }^{3}$ Department of Pediatrics, Gulhane Military Medical Faculty, Ankara, Turkey

${ }^{4}$ Department of Pediatric Cardiology, Gulhane Military Medical Faculty, Ankara, Turkey

${ }^{5}$ Department of Neonatology, Gulhane Military Medical Faculty, Ankara, Turkey

${ }^{6}$ Department of Biochemistry, Gulhane Military Medical Faculty, Ankara, Turkey

\begin{abstract}
Background: The gastrointestinal system constitutes an important part of immune system in newborns. Toll-like receptors (TLRs) are pattern recognition molecules that initiate innate immune responses in newborn gut. The aim of the study was to investigate the responsiveness of intestinal Toll-like receptors 2 (TLR-2), TLR-4 and TLR-9 levels to postnatal steroid therapy.

Material and methods: Rats were randomly assigned to three experimental groups. Group I (control at day 0$)(n=9)$, group II (control at day 10) $(n=9)$ : oral distilled water, group III (study group) $(n=9)$ : oral dexamethasone $(0.5 \mathrm{mg} / \mathrm{kg} /$ day $)$. After 10 days, the ileojejunal segment was removed for biochemical analyses of TLR-2, TLR-4 and TLR-9.

Results: There was no statistically significant difference between groups for TLR-2 and TLR-4 levels. There was a significant difference between groups for TLR-9 levels. There were no significant difference between group I and III and both groups were significantly higher than group II for TLR-9 levels.

Conclusions: Postnatal steroid treatment may reduce TLR-4 level via increasing the level of TLR-9. Thus, it may lead to limited beneficial and protective effect against necrotizing enterocolitis which is a deleterious disease of the newborn gastrointestinal tract.
\end{abstract}

Key words: Toll-like receptor, dexamethasone, newborn, intestine.

(Centr Eur J Immunol 2012; 37 (4): 303-306)

\section{Introduction}

The maturation of the gastrointestinal tract in the neonates is a dynamic process which is not completed at birth [1, 2]. However, the barrier function of gastrointestinal tract continues to develop after birth [3, 4]. The gastrointestinal tract is the largest surface area of the body and intestinal microflora plays a direct impact on maintaining the gut homeostasis by inducing immune responses $[5,6]$. The commensal microbiota in the newborn gut is recognized by pattern recognition receptors (PRRs), which in turn regulate mucosal innate immunity and inflammatory responses [7]. Toll-like receptors (TLRs) are the first dis- covered and the most well-characterized member of PRRs and detect microbe associated molecular patterns (MAMPs) present in a wide range of microorganisms [7]. Toll-like receptors at intestinal epithelial cells should be a key sensory system in recognizing enteric microbes, which in turn alters the intracellular signaling within the gut epithelial cells and leads to activating innate and inflammatory responses $[8,9]$.

Necrotizing enterocolitis (NEC) is the most common gastrointestinal emergency affecting premature infants in the neonatal intensive care unit (NICU) [10-12]. The pathophysiology of NEC is incompletely understood but is thought to involve a combination of gastrointestinal tract

Correspondence: Abdulbaki Karaoglu, Assistant Professor, Department of Pediatrics, Gulhane Military Medical Faculty, Ankara, Turkey 06018, phone: 90312304 1889, fax: 90312304 4381, e-mail: akaraoglu@gata.edu.tr 
immaturity, enteral feeds, hypoxia and bacterial colonization.

The effects of antenatal and postnatal steroid therapy to accelerate fetal lung maturation and prevent bronchopulmonary dysplasia (BPD), respectively, on NEC in preterm infants have been investigated $[13,14]$. Although it has been shown in several studies that antenatal steroid therapy reduces the incidence of NEC, a limited number of studies were in favor of the effects of postnatal steroid therapy on NEC $[15,16]$. In this experimental study, we investigated the effect of steroid therapy on TLR-2, TLR-4 and TLR-9 levels in order to have an idea about the effects of steroid therapy on NEC, a common and deleterious disease of newborn intestine, that has been related with increased TLR-4 expression in immature intestine.

\section{Material and methods}

\section{Animal model}

Ethical approval was obtained from the experimental animal ethics committee at Gulhane Military Faculty of Medicine (Ankara, Turkey). Three time-mated Sprague-Dawley pregnant rats obtained from the Gulhane Military Medical Faculty Experimental Research Unit were delivered spontaneously. Three groups were allocated from 27 pubs as follows: group I (control at day 0) $(n=9)$ ), group II (control at day 10) $(n=9)$, group III (study group) $(n=9)$. The rat pups were housed with their mothers in the same cage and maintained at room temperature with a natural day and night cycle and ad libitum access to standard rat chow tap water. Baby rats were randomly selected and marked on postnatal day 1 and divided equally into 3 groups.

Group I was sacrificed immediately after birth. Starting from day 1 until day 10, group II received breast milk and distilled water, group III received breast milk and $0.5 \mathrm{mg} / \mathrm{kg} /$ day dexamethasone. Dexamethasone supplement was dissolved in distilled water and fed to the rat pups through a 24-gauge angiocath with the help of an injector.

\section{Tissue preparation}

Baby rat pups were sacrificed by cervical dislocation. The ileojejunal part of intestine was removed and washed with $0.9 \% \mathrm{NaCl}$ to remove residual blood, put into tubes, frozen in liquid nitrogen, and stored at $-70^{\circ} \mathrm{C}$ for biochemical analysis immediately after birth from group I and a 10-days period from group II and III.

\section{Biochemical analysis}

\section{Homogenate preparation}

The frozen tissues were homogenized in phosphate buffer solution ( $\mathrm{pH}: 7.4$ ) by means of a homogenizator (Heidolph Diax 900; Heidolph Elektro GmbH, Kelhaim, Germany) on an ice cube. Homogenates were centrifuged at $14.000 \mathrm{rpm}$ in $4^{\circ} \mathrm{C}$ for $10 \mathrm{~min}$. The supernatants were used for entire assays. The protein content of tissue homogenates was measured by the method of Lowry [17].
Measurements of rat Toll-like receptor 2 (TLR-2), 4 (TLR-4) and 9 (TLR-9)

We used enzyme-linked immunosorbent assay (ELISA) kits according to the manufacturer's instructions (Cusabio Biotech Co., Ltd., Hubei Province, P.R. China) to determine the tissue TLR-2, TLR-4 and TLR-9 concentrations. In briefly, the microtiter plate has been pre-coated with an antibody specific to TLR-2, TLR-4 and TLR-9. Standards or samples are added to the appropriate microtiter plate wells with biotin-conjugated antibodies preparation specific for TLR-2, TLR-4 and TLR-9. Then Avidin conjugated to horseradish peroxidase is added to each microplate well and incubated. Then a TMB (3,3',5,5'-tetramethylbenzidine) substrate solution is added to each well. Only those wells that contain TLR-2, TLR-4, TLR-9, biotin-conjugated antibody and enzyme-conjugated Avidin will exhibit a change in color. The enzyme-substrate reaction is terminated by the addition of a sulphuric acid solution and the color change is measured spectrophotometrically at a wavelength of 450 $\pm 2 \mathrm{~nm}$. The concentrations of TLR-2, TLR-4 and TLR-9 in the samples are then determined by comparing the O.D. of the samples to the standard curves. The intra-assay and the inter-assay coefficients of variation for all assays were $<8 \%$ and $<10 \%$, respectively. We measured all samples in duplicate. Tissue TLR-2, TLR-4 and TLR-9 concentrations were expressed as $\mathrm{pg} / \mathrm{mg}$ protein, $\mathrm{ng} / \mathrm{mg}$ protein and $\mathrm{ng} / \mathrm{mg}$ protein, respectively.

\section{Statistical analysis}

SPSS for Windows version 15.0 (SPSS, Chicago, IL) was used for statistical analyses. $P<0.05$ were accepted as indicating a statistically significant difference. A KruskalWallis test was used for testing differences and a MannWhitney $U$-test was used for comparing groups with each other and with the control group to determine the source of the difference among study groups.

\section{Results}

Figure 1 summarizes TLR-2, TLR-4, and TLR-9 levels in homogenates of intestinal tissue taken from all of the groups. There were no statistically difference between groups for TLR-2 and TLR-4 levels $(p>0.05)$. There was a significant difference between groups for TLR-9 levels $(\boldsymbol{p}<\mathbf{0 . 0 5})$. There were no significant difference between group I and III and both groups were significantly higher than group II for TLR-9 levels (Table 1).

\section{Discussion}

In this study, we evaluated the alteration in TLR-2, TLR-4, and TLR-9 levels in newborn intestine of first ten days of postnatal life and the effect of oral dexamethasone. There was no significant difference between study and control groups for TLR-2 and TLR-4 levels, whereas TLR-9 
Table 1. Comparison of Toll-like receptor levels between groups

\begin{tabular}{|c|c|c|c|c|c|}
\hline Groups & Group I & Group II & Group III & $p$ & $p$ \\
\hline $\begin{array}{l}\text { TLR-2 } \\
\text { (pg/mg protein) }\end{array}$ & $\begin{array}{c}17.28 \\
16.04 ; 28.98\end{array}$ & $\begin{array}{c}16.70 \\
11.62 ; 19.39\end{array}$ & $\begin{array}{c}18.32 \\
14.24 ; 19.46\end{array}$ & NS & \\
\hline $\begin{array}{l}\text { TLR-4 } \\
\text { (ng/mg protein) }\end{array}$ & $\begin{array}{c}0.15 \\
0.00 ; 0.90\end{array}$ & $\begin{array}{c}0.15 \\
0.00 ; 0.88\end{array}$ & $\begin{array}{c}0.27 \\
0.00 ; 0.75\end{array}$ & NS & \\
\hline $\begin{array}{l}\text { TLR-9 } \\
\text { (ng/mg protein) }\end{array}$ & $\begin{array}{c}0.51 \\
0.42 ; 0.67\end{array}$ & $\begin{array}{c}0.41 \\
0.27 ; 0.50\end{array}$ & $\begin{array}{c}0.59 \\
0.49 ; 0.79\end{array}$ & $\begin{array}{l}\text { G.GG2 } *<\mathrm{G}{ }^{0} 5 \\
<\mathrm{G} . \mathrm{GG} 1 * * *\end{array}$ & NS \\
\hline
\end{tabular}

All data are expressed as median, minimum and maximum. $P<0.05$ are considered as significant. NS - not significant, *comparison of group $* 1-2 ; * * 1-3 ; * * * 2-3$

level in group II was significantly lower than group I. Tolllike receptor 9 levels did not decreased with time and remained high during study period in group III.

Postnatal glucocorticoids such as dexamethasone and hydrocortisone are often used in the prevention and treatment of BPD in preterm infants. In some of these studies evaluate the effect of postnatal steroid therapy on NEC displayed an increase in short term side effects such as gastrointestinal perforation and bleeding. However, these kinds of treatments have been reported to have a limited impact on the incidence of NEC. A study by Doyle et al. showed that postnatal steroid treatment given to prevent BPD has little beneficial effect on the incidence of NEC [18]. A study performed by Halac et al. reported that postnatal dexamethasone therapy was not as effective as prenatal administration although it has reduced the incidence of NEC. In another study, treatment with cortisone while decreasing TLR-2 and TLR-4 mRNA levels in human intestinal xenografts increased mRNA levels of negative regulators (TOLLIP and A20) by measuring with quantified RT-PCR technique [19]. In our study, TLR-9 levels were remained high in the study group. Recent studies have shown that TLR-9 has a preventive effect against NEC by limiting the extent of TLR-4 signaling plays a pivotal role in the pathogenesis of NEC [20]. We asses that the beneficial effect of steroids on newborn gut in our study may be related with increased levels of TLR-9. Furthermore the beneficial effect of postnatal steroids in NEC might be associated with increased TLR-9 expression.

The reciprocal expression of TLR- 9 and TLR- 4 was found to influence the extent of TLR-4 signaling, and the development of the NEC was accompanied by a relative increase in TLR-4 with a concomitant reduction in the TLR9 [21]. Therefore increased TLR-9 levels might provide a balance of uncontrolled proinflammatory cytokine production in newborn gut by reducing TLR-4 expression. In addition, steroid induced increase of mRNA expression of negative regulatories in immature gut might be the cause of occurrence of this beneficial effect.

The another aim of the study was to determine whether dexamethasone has any effect on TLR-2 and TLR-4 levels, the receptors for bacterial ligands associated with gram-pos-

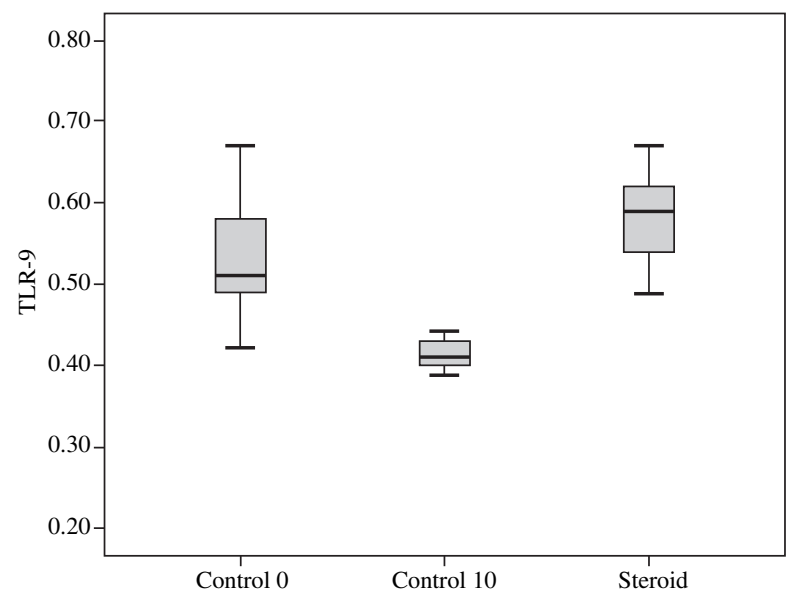

Fig. 1. Toll-like receptor 9 levels of the groups

itive and gram-negative bacteria, respectively. Toll-like receptor 2 recognizes numerous microbial components of gram-positive bacteria such as peptidoglycan and lipoproteins, despite that TLR-4 are required for lipopolysaccharide responsiveness which is the outer component of the membrane of gram negative bacteria [22, 23]. We did not observe any change in TLR-2 and TLR-4 levels during study period. In a study, it has been reported that TLR-4 are highly expressed on the surface of immature intestinal enterocytes and these receptors become unregulated with inflammation [24]. However, it has been shown that TLR-4 receptors are internalized in mature intestinal enterocytes [25]. In this study, the reason why TLR-4 levels have not changed over time could be explained by sufficient maturation of newborn rat intestine in first ten days of postnatal life.

In conclusion, postnatal steroid therapy may provide beneficial effect in newborn intestine by increasing TLR-9 levels. There is no study examining the effects of postnatal steroid therapy on intestinal TLR levels in the literature. In this regard, this study is the first examining the effects of postnatal steroids on TLR-2, TLR-4, and TLR-9 levels in newborn rat intestine. We suggest that further studies aiming to include the application of antenatal steroids in a NEC 
model may contribute to better understanding of the pathogenesis of NEC.

The authors declare no conflict of interest.

\section{References}

1. Weaver LT, Laker MF, Nelson R (1984): Intestinal permeability in the newborn. Arch Dis Child 59: 236-241.

2. van Elburg RM, Fetter WP, Bunkers CM, Heymans HS (2003): Intestinal permeability in relation to birth weight and gestational and postnatal age. Arch Dis Child Fetal Neonatal Ed 88: F52-55.

3. Beach RC, Menzies IS, Clayden GS, Scopes JW (1982): Gastrointestinal permeability changes in the preterm neonate. Arch Dis Child 57: 141-145.

4. Sevastiadou S, Malamitsi-Puchner A, Costalos C, et al. (2011): The impact of oral glutamine supplementation on the intestinal permeability and incidence of necrotizing enterocolitis/septicemia in premature neonates. J Matern Fetal Neonatal Med 24: 1294-1300.

5. Husebye E, Hellström PM, Sundler F, et al. (2001): Influence of microbial species on small intestinal myoelectric activity and transit in germ-free rats. Am J Physiol Gastrointest Liver Physiol 280: G368-380.

6. Rhee SH, Im E, Riegler M, et al. (2005): Pathophysiological role of Toll-like receptor 5 engagement by bacterial flagellin in colonic inflammation. Proc Natl Acad Sci U S A 102: 13610-13615.

7. Palm NW, Medzhitov R (2009): Pattern recognition receptors and control of adaptive immunity. Immunol Rev 227: 221-233.

8. Medzhitov R (2007): Recognition of microorganisms and activation of the immune response. Nature 449: 819-826.

9. Kenny EF, O’Neill LA (2008): Signalling adaptors used by Toll-like receptors: an update. Cytokine 43: 342-349.

10. Henry MC, Moss RL (2008): Neonatal necrotizing enterocolitis. Semin Pediatr Surg 17: 98-109.

11. Kafetzis DA, Skevaki C, Costalos C (2003): Neonatal necrotizing enterocolitis: an overview. Curr Opin Infect Dis 16: 349-355.

12. Hunter CJ, Upperman JS, Ford HR, Camerini V (2008): Understanding the susceptibility of the premature infant to necrotizing enterocolitis (NEC). Pediatr Res 63: 117-123.

13. Crowley P (2000): Prophylactic corticosteroids for preterm birth. Cochrane Database Syst Rev 2: CD000065.

14. Smrcek JM, Schwartau N, Kohl M, et al. (2005): Antenatal corticosteroid therapy in premature infants. Arch Gynecol Obstet 271: 26-32.

15. Bontis N, Vavilis D, Tsolakidis D, et al. (2011): Comparison of single versus multiple courses of antenatal betamethasone in patients with threatened preterm labor. Clin Exp Obstet Gynecol 38: 165-167.

16. Thompson AM, Bizzarro MJ (2008): Necrotizing enterocolitis in newborns: pathogenesis, prevention and management. Drugs 68: 1227-1238.

17. Lowry OH, Rosebrough NJ, Farr AI, Randall RJ (1951): Protein measurement with the Folin phenol reagent. J Biol Chem 193: 265-275.

18. Doyle LW, Ehrenkranz RA, Halliday HL (2010): Dexamethasone treatment in the first week of life for preventing bronchopulmonary dysplasia in preterm infants: a systematic review. Neonatology 98: 217-224.
19. Nanthakumar N, Meng D, Goldstein AM, et al. (2011): The mechanism of excessive intestinal inflammation in necrotizing enterocolitis: an immature innate immune response. PLoS One 6: e 17776 .

20. Afrazi A, Sodhi CP, Richardson W, et al. (2011): New insights into the pathogenesis and treatment of necrotizing enterocolitis: Toll-like receptors and beyond. Pediatr Res 69: 183-188.

21. Gribar SC, Sodhi CP, Richardson WM, et al. (2009): Reciprocal expression and signaling of TLR4 and TLR9 in the pathogenesis and treatment of necrotizing enterocolitis. J Immunol 182: 636-646.

22. Reis e Sousa C (2004): Toll-like receptors and dendritic cells: for whom the bug tolls. Semin Immunol 16: 27-34.

23. Bell JK, Mullen GE, Leifer CA, et al. (2003): Leucine-rich repeats and pathogen recognition in Toll-like receptors. Trends Immunol 24: 528-533.

24. Fusunyan RD, Nanthakumar NN, Baldeon ME, Walker WA (2001): Evidence for an innate immune response in the immature human intestine: toll-like receptors on fetal enterocytes. Pediatr Res 49: 589-593.

25. Abreu MT (2010): The Ying and Yang of bacterial signaling in necrotizing enterocolitis. Gastroenterology 138: 39-43. 